\title{
The Travailes of the Three English Brothers and the Textual Construction of Early Modern Identities
}

\author{
JESÚS LÓPEZ-PELÁEZ CASELLAS
}

\begin{abstract}
Day, Rowley and Wilkins's travel and adventure play The Travailes of the Three English Brothers (1607) dramatises the misadventures of the three Sherley brothers between 1597 and the year of composition of the play. The playwrights, drawing on contemporary writings on/by the Sherleys and their adventures through Turkey, Persia, Venice and Rome, apparently attempted to compose an ideological dramatization of English identities based on cultural and religious difference and English superiority over Muslim (Persian and Ottoman) and Jewish others. However, I will suggest that the play also presents English and Christian identities in a constant state of flux and confusion, contradicting its apparent compliance with a process of identity-building mainly based on confrontation in order to replace it with an alternative approach to religious and political alterity which I have called, following Juri Lotman, symbiotic. This is achieved at both textual and metatextual levels through a number of semiotic and rhetorical strategies which articulate the play's insertion into various contemporary discussions on nascent capitalism, religious sectarian differences, England's encounter with other cultures, and the nature of the Sherleys' exploits. The employment of metatheatrical techniques - like the confusion of the various levels of factuality involved (through the complex mingling of diverse pseudo historical sources) and of various dramatic devices (such as dumb shows, parades, or choruses, and the insertion, as a character in the play, of the Elizabethan actor Will Kemp) question any reading that attempts to privilege a discourse of English protocolonialism as opposed to Muslim (Persian and Ottoman) otherness.
\end{abstract}

Keywords: John Day; William Rowley; George Wilkins; Travels of the Three English Brothers; Anthony; Thomas and Robert Sherley; Persians; Ottomans; Jews; travel \& adventure play; Islam; early modern England; identities and alterity; protocolonialism; metatheatricality 
LÓPEZ-PELÁEZ CASELLAS

\section{Introduction}

A careful and close reading of John Day, William Rowley, and George Wilkins's The Travailes of the Three English Brothers $(1607)^{1}$ cannot fail to emphasise the play's direct and undeniable indebtedness to a diversity of sources and related documents, travel narratives and pamphlets mainly, dealing with the (mostly failed) geo-political projects of the three Sherley brothers, Thomas, Anthony and Robert. These texts were almost contemporary both to the composition, acting and publication of the play, and to the historical and almost unbelievably hazardous central events dramatised (literally unfinished as the play went to the press): namely, Anthony and Robert Sherley's arrival in Persia in December 1598 and their success at the Safavid kingdom; their subsequent Persian embassy to several European (mostly Hapsburg) courts between 1599 and 1601 and Anthony Sherley's uncertain role in it; Thomas Sherley's captivity and release from an Ottoman prison between 1603 and 1605; and Robert's marriage to Shah Abbas's niece, his promotion from hostage to Shah's ambassador to Europe, and the alleged christening of his first child in Persia (all this between 1599 and 1609). ${ }^{2}$

The almost simultaneous development of the three brothers' adventures and the writing and acting of the play - which explains the audience's awareness of (and interest in) the Sherleys' exploits - together with the - as we will see - contradictory accounts that various sources and other documents give us of this narrative, contributes to a problematization of the play's apparent purpose, which evidently was the propagandistic advancement of the three

Throughout this essay I used three texts: the Quarto edition of 1607 electronically edited by Chadwyck \& Healy; Anthony Parr's 1995 edition for Manchester University Press, which collates four extant copies of the Quarto; and the Folger Shakespeare Library copy (32 unnumbered leaves, A to $\mathrm{H} 4$ ). I have found no significant differences among these versions except for one line in the Folger copy (H3). All quotations are from Parr's edition. I am thankful to the Folger Shakespeare Library for a generous grant, permission to access its vast material during the summer of 2010, and - above all - the kindness of all the staff. I am also grateful to the staff at the Cervantes Hall of the Biblioteca Nacional de España in Madrid.

2 It must be noted that the Sherley brothers (Thomas, Anthony and Robert) did not disappear from the European political arena in 1607, and until the late 1620 s we can still trace Anthony and Robert at least as minor actors, mostly out of England. According to Francisco Hernández de Jorquera in his Anales de Granada, Sir Anthony (self-styled, in Spain, 'conde de leste') died in 1633 in Granada and was buried at the Saint Peter and Saint Paul's church, at the feet of the Alhambra (Davies 1967: 281-286; Hernández de Jorquera 1987: 740; Ross 1933: 3-90; Chew 1937: 239-339). 
brothers' reputation and status, ${ }^{3}$ and in a more general sense the theatrical construction of English identities. These identities, in principle, appear to be defined by means of the presentation on stage of Christian (both Protestant and Catholic) and English superiority over Muslim (Persian and Ottoman) and Jewish others, and this superiority would be exemplified by the three brothers' deeds in Persia and through the Mediterranean, and reproduced by means of somewhat simplistic but very effective mechanisms of opposition (Cohen's 'strategic identity,' [Cohen 1993: 198]) and appropriation (Burton's 'imperial rhetoric of appropriation' of English early modern texts [Burton 2009: 40]).

According to such a perceptive reader of this play as Anthony Parr, texts such as Day, Rowley, and Wilkins's Travailes articulate "in embryonic form ... the British imperial idea, ... laying the foundations of national attitudes" (Parr 1996: 30). But a close reading of the play against the sources and contemporary accounts of the Sherley brothers' travels leaves us with a very different impression. The pattern of honorable and heroic behavior that the exploits of the three brothers seems to outline, and the model of construction of English and Christian identities that The Travailes of the Three English Brothers ${ }^{4}$ tries to fashion, both appear in a constant state of flux and confusion and not in the univocal, unambiguous way that we could expect from the patriotic, protoimperialistic, text that Parr's analysis seems to outline.

Furthermore, the play has not only been accused of simplicity in terms of its content, i.e., the dramatic treatment of its semi-historical material (the Sherleys' exploits), but also of lacking dramatic and semiotic sophistication. Indeed, two insightful critics of The Travailes of the Three English Brothers, H. Neville Davies and Peter Holland, have both emphasised the existence of an incompatibility within the play that prevents it from achieving a formal pattern (Holland 1996: 167; Davies 1986: 104). This lack of a stylised form, they claim, has to do with the constant and apparently unsystematised flow of the three brothers' stories, which are - according to Holland - presented in a way that passes freely from dumb show through mime to narration (Holland 1996: 167). This complex dramatic structure (or lack of it) has been defined by Neville Davies as an "opportunistic and unsystematic mixing of media" which he finds "unsettling" (Davies 1986: 104). For Neville Davies Travailes is a "loose baggy monster" (ibid. 105), a "pot-boiler" with no "natural shape" (ibid. 107) or "real

3 In fact, the play was probably commissioned by Thomas Sherley himself (Parr 1995: 1-54; Chew 1937:287).

4 Henceforth, Travailes. I will give scene and line reference. 
LÓPEZ-PELÁEZ CASELLAS

imaginative power" which he unfavorably compares to Shakespeare's Pericles (ibid. 98). ${ }^{5}$

Travailes, I will suggest, contradicts its apparent compliance with a simplistic process of identity-building mainly based on confrontation, opposition and appropriation and develops, instead, a symbiotic ${ }^{6}$ approach to alterity or, in other words, to economic, religious, ethnic and political difference which is, itself, full of uncertainty and contradiction. I will also claim that the play, as Holland himself cannot fail to note, "manipulates conventions of theatre in a sophisticated way", transcending reality and achieving "fluidity and fluency" (Holland 1996: 168). To be sure, these unsettling incompatibilities go beyond formal structure and point to the various conflicts, contradictions, gulfs and gaps that I will examine and which, as I expect to show, address Turkish, Persian and English triangular relations in terms of culture, religion, economy and gender. These contradictions and uncertainties, then, will be examined as not only the consequence of textual (dramatic) discontinuities (central as they certainly are), but linked to the production and reception of this play and to its insertion into an interplay of significance between play, pre-texts, and the literally ongoing Sherleyan adventure.

\section{The Sherleyan adventure according to the sources}

The events dramatized in the play are well documented through various contemporary testimonies, both eye-witness accounts and second-hand narratives, from a variety of actors with different investments in the story. Anthony Nixon's pamphlet The Three English Brothers, from 1607, is a primary source of Travailes that contains most of the pseudo-historical episodes developed in the play, namely the Persian diplomatic mission at the head of which Sir Anthony and the Persian ambassador Hussein Ali Beg were allegedly appointed by the 'Great Sophy' (as the Persian Shah was known by

Chew had already called it a "hotch-potch" (1937: 508).

6 Although according to the Oxford English Dictionary Online the term 'symbiosis' was already employed in the early modern period to refer to 'social life', I borrow it from biology to refer to a productive or collaborative association of different organisms. I also employ this concept in a Lotmanian sense since, although Juri Lotman never used the actual term 'symbiosis', "the embryo of a symbiotic approach to culture was quite early present in his work" (Talvet 2013: 25). For Lotman, a symbiotic approach to culture and the self involved, roughly speaking, "to enter into an open contact with the other," understood as a foreign semiotic space; this notion complements the biological approach mentioned above (ibid. 26). 
The Travailes of the Three English Brothers and the Textual Construction

early modern audiences). Significantly as we will see, Nixon's text entered the Stationer's Register on the first week of June 1607, whereas Travailes did so on June 29,1607, that is, only three weeks later and while it was still being acted (probably either at the Curtain or the Red Bull) in direct competition with Shakespeare's Pericles (staged at the Globe).

But Nixon's pamphlet itself was based on three other earlier and direct sources of the Sherleys' narrative, written by actual participants in the three brothers' adventures, and from which Nixon literally lifted whole passages: ${ }^{8}$ the anonymous A True Report of Sir Anthony Sherley's Journey (1600); William Parry's A New and Large Discourse of the Travels of Sir Anthony Sherley, Knight (1601); ${ }^{9}$ and George Manwaring's A True Discourse of Sir Anthony Sherley's Travel into Persia (1601). ${ }^{10}$ The two anonymous authors of the True Report the first of these narratives to be published) were members of the aforementioned diplomatic mission, and they had arrived in Isfahan in 1598 together with Sir Anthony; their narrative, like those of Parry and Manwaring, includes relevant documents (such as the commercial privilege obtained by Sir Anthony from the Sophy allowing Christians to trade in Persia) ${ }^{11}$ and concludes with Sir Anthony's arrival in Prague in October 1600 (Davies 1967: 114-140, esp. 124-132; Ross 1933: xv; Chew 1937: 266-69). Equally, both Manwaring and Parry - the authors of the other two pamphlets - belonged to that same contingent when it arrived inthe Russian court of Boris Godunov in November 1599, leaving then for England with letters for - as it seems - the Earl of Essex. ${ }^{12}$

7 Cf. Nixon 1607. The exact relation existing between Travailes and Nixon's pamphlet is still uncertain, since although the play seems to be undeniably indebted to Nixon's text (or to an earlier manuscript of that text), it went onto the stage before Nixon's pamphlet had been printed. Cf. Parr (1995: 7-8); Davies (1986: 94-95).

8 These texts have been published by E. D. Ross (1933).

9 Parry's pamphlet was published with the intention of replacing the anonymous True Report which was suppressed because - as it seems - it was published without licence and using Parry's notes.

10 There are some other documents in English composed and/or published after the play was published, namely, two of the brothers' first person accounts of their travels and adventures: Sir Anthony Sherley. His Relations of his Travels into Persia (1613); and Thomas Sherley's Discours of the Turks (1617), and also Thomas Middleton's Sir Robert Sherley (1609), a pamphlet in all likelihood written for pay.

11 According to the Calendar of State Papers, Colonial Series, Shah Abbas "sent over by Sir Anthony Sherley a declaration of his desire to be at peace with the Christian Princes" (Sainsbury 1864: 103).

12 Samuel Chew informs us that the letters were intercepted by Sir Robert Cecil's spies; unfortunately for Sir Anthony, who was already considered suspect of acting against England's interests, the letters contained "indiscreet expressions of passionate loyalty" 
It was in London where they composed their narrative from notes taken on the spot and - at least in the case of Parry - as a reaction to the anonymous publication of A True Report (Sha'ban 1965: 185-88; Chew 1937: 268).

After having examined all these texts, the ideological purpose of the play and of most related texts, Nixon, who is probably the most conspicuous of all pamphleteers in his praise of the three brothers, says that they are "worthy personages whose Noble spirits... have drawn other Nations into admiration of their valours and emulation of their virtues," and calls them "the Three Heroes of our Time; ... Honour by them - he state - has added to her [i.e., England's] glory" (Nixon 1607: B-B2). Sir Anthony's own account also emphasises a strong concern with his own reputation, just like Thomas Middleton's pamphlet on Robert Shirley, Manwaring's andParry's travel accounts, or the anonymous True Report (Sherley 1613: 64; Ross 1933: 207, 100, 92). Indeed, according to the play, it was "Fame" with her "proclaiming trump" which "sounded the travels of our English brothers;" (Travailes, epilogue 1-2); likewise, Fuad Sha'ban (the first modern editor of the play) informs us that "in the eyes of Englishmen in the first decade of the seventeenth century, the Sherleys were popular heroes" (Sha'ban 1965: 184). It can be argued that honor is one central cultural semiotic concern in the play, and a reading of Travailes a play evidently very much concerned with English honor abroad - makes clear that the Sherley brothers' voyages and adventures were to a great extent ruled by the pursuit of honor. This is probably why both Nixon's and Middleton's pamphlets and Day, Rowley and Wilkins's play were commissioned by the eldest brother, Thomas, with the evident purpose of enhancing the brothers' reputation and emphasizing the strategic relevance of their already evidently self-appointed goal of fostering England's role as Persia's main Christian ally (Chew 1937: 287).

This propagandistic intention was also difficult to sustain as the real nature of the three brothers' exploits became apparent for larger sections of English society. As we have seen, there was sufficient evidence that, for the English government, Sir Anthony had already gone rogue, something which was made

to Essex, Cecil's greatest enemy (1937:266). Aware of how dangerous his allegiance to Essex now was, in a letter later addressed to Sir Robert Cecil Sir Anthony tried to explain that he followed the Earl "constrained by extremest necessity", and bitterly complained of the negative consequences this had brought to him: "all has been lost with one man. I wished my actions to be considered apart from the Earl of Essex" (Green 1870: 224). The play captures some of Sir Anthony's problems with the English establishment and powers-that-be (the Queen and Cecil, the Levant Company, and the Privy Council) (Travailes 1.139-47; 156). 
The Travailes of the Three English Brothers and the Textual Construction

finally clear by his simultaneous services to various monarchs and his ignoring English geo-political interests. At the time of the acting of the play Sir Anthony had already converted to Catholicism and was actually in the service of King Philip III of Spain (later he would also serve Philip IV). This information was briefly included in the epilogue of the play as a final comment by the Chorus (dressed as 'Fame'): "Sir Anthony Sherley we have left in Spain / Knight of St Iago,... / Captain of th'Armado.” (Travailes, epilogue 16-17, 19). This was probably common knowledge at the time since it also appeared in Nixon's pamphlet. ${ }^{13}$ As for Thomas Sherley, the letter-writer John Chamberlain evinces not only the gap between the play's heroic dramatization of the eldest Sherley brother and his real achievement as an unsuccessful privateer, but also the extent to which this was known at the time (Williams 1861: 144). ${ }^{14}$

\section{The Travailes of the Three English Brothers and the construction of identities}

In a typically proto-colonial fashion Travailes introduces early on the first Persian admissions of English superiority. After a victorious campaign against the Uzbegs (which is actually a historical allusion to Shah Abbas' succesful campaign of 1598 in Uzbegistan), Sir Anthony Sherley is encouraged by the Governor of the frontier town of Qasvin to salute the returning victorious Sophy by shooting his never-previously seen English weapons:

Which would you greete with your high tongues of warres,

Whose thunder nere was heard in Persia:

Till you gaue voice to them at Casbin first.

(Travailes, 1.21-23).

The mock battles dramatised in this first scene, and the sense of awe that this English military performance apparently had on Persians in the play, reproduces the kind of reciprocal comparison that plays about the English

13 "The King [i.e., Philip III] installed him one of the Knights of the Honourable Order of S. Iago, and created him Captaine of his Galleyes for the warres against the Turkes" (Nixon 1607: I4 $-\mathrm{K} 1$ ).

${ }_{14}$ To further complicate things, there exists an additional non-English early seventeenth century account of the Persian embassy and of Sir Anthony Sherley's role in it, one written by the Persian ambassador's secretary Uruch Beg, and which sheds a very different light on this historical episode. Cf. Persia 1929 (1604); Burton 2009: 30-37. 
LÓPEZ-PELÁEZ CASELLAS

encounter with the Orient used to develop, and which had the overt intention of asserting English superiority over the non-English: in our case the Shah's army will be subsequently presented as a product of the Sherleys' transmission of their military skills, themselves evidence of English and European superior knowledge of warfare (Chew 1937: 257-258; Ross 1933: 20). Furthermore, later in the play and as a consequence of his great victories, the youngest Sherley brother, Robert, will be awarded the title of "Sherley the Great" (Travailes, 11.104) by common Persians, who gladly acknowledge his soldierly proficiency and accept his position as General of the Persian army.

But this imperialistic scripting of Persian inferiority was too clearly based on a blatant historical distortion to be taken as the only available or acceptable reading of scene one, since Persians knew and actually manufactured artillery, and firearms and gunpowder were well known in Persia long before the arrival of the Sherleys, as some authors had already explained to their English readership; thus, Manwaring writes:

although there are some which have written now of late that they [i.e., Persians] had not the use of pieces until our coming into the country, this much must I write to their praise, that I did never see better barrels of muskets than I did see there (Ross 1933: 222).

If we add to this Sir Anthony's earlier questionable military record - he had returned defeated and empty-handed from his expeditions to the Caribbean and Thomas's previously mentioned failed campaigns in the Mediterranean and elsewhere, we may assume that for the audience of the play this may have been the first of various confusing and dubious allusions to English (pretendedly) superior military skills and to the (failed) exploits of the Sherleys in Persia and Europe.

The play also appears to emphasise English ascendance regarding moral and ethical values. Travailes (although significantly never reproducing the standard view of a Muslim country as a haven of hedonism, emasculation and effeminacy) seems to underline, in the context of a play set abroad, both English higher moral substance and stronger determination (in the case of Thomas' resilience, in scenes eight and twelve), and even a reflexive masculinity (Robert, in scene three) which immediately captures the erotic imagination of Persian women. About the former, the play focuses on the eldest Sherley brother, Thomas, a captive of the Turks for the most part of the play, who is cruelly tortured by these in order to find out who he really is (they suspect he is of noble 'blood'), but proudly manifests his unmoved will and stable 
The Travailes of the Three English Brothers and the Textual Construction

human identity in the face of atrocious pain by means of less than metaphorical allusions to his blood, heart and 'vitals':

Even in these outstretched veines,

Liues my amaselesse vitals, heres an vndaunted heart,

That neuer yeelds by Turkish tyranny:

I am the same, through all that made me man,

Scorne Pagans threats, to die a Christian.

(Travailes, 12.95-99).

Travailes is frequently at pains to demonstrate English superiority over Turkish - but not Persian - culture. Like Linda McJannet already explained for Marlowe's Tamburlaine plays, the Persians' Islamic religion “is downplayed," while a clearly distinct Muslim identity is created for the Turks (McJannet 1999: 246). But even if - as we will see - it is later promoted to a quasi-Christian status, Persian culture is initially presented as static and paralyzed in the first two scenes of the play. Thus, the first exchanges between Sir Anthony and the Sophy clearly resemble those reported in the New World with the native peoples encountered there by Spanish conquistadors. Unlike other episodes later in the play, these preliminary exchanges seem to present Persian culture as an example of - following Lotman's term - nonculture. 'Noncultures' are constructed as spaces based on entropy (chaos) and non-organization, and are perceived by 'cultures' as the sphere for their potential expansion, or as places where an 'imperial rhetoric' (of the kind Burton defined) can be practiced. Hence, the Shah's admiration for English technology and culture, and more specifically for Sir Anthony: "Methinks this Christian's more than mortal. ... I wish to be no other but as he" (Travailes, 1. 75, 79). ${ }^{15}$ 'Cultures' always see themselves as active principles, and their growth at the expense of 'noncultures' (like New World peoples, Ottomans, or Persians at the beginning of the play) is never questioned. An absolute evil and a radical otherness are predicated upon non-cultures, but while Ottomans (as in the quote above) will consistently be portrayed in this fashion, Persians on their part will soon cease to be reproduced as non-cultural objects in order to constitute an 'anticulture', which is "constructed isomorphically to culture, in its own image" (Lotman and Uspenskij 1978: 220). The consequence of this is that Persians, unlike Ottomans, may be - the play argues - redeemed. Yet, this will not be immediately apparent, and in the first scenes of the play, and as part of what much of the audience probably expected, Persians become the mirror image of

15 Also: "Sure this is a God" (1.118). 
LÓPEZ-PELÁEZ CASELLAS

Englishmen; this means that - originally at least - the play wants to project a relation based on a radical inequality, like the one attributed to the exchanges between Spaniards and Aztecs. ${ }^{16}$

Probably because he did not write his own account of his years in Persia we do not have many details of Robert's marriage, but the three playwrights made much of this episode of his life, which was quite centrally presented and symbolically related in the play to English superiority over Persians. ${ }^{17}$ To be sure, Nixon mentions how, some years after Sir Anthony's departure from Isfahan in 1599 (where he was forced to leave Robert as warrant of his loyalty to the Shah) Robert married the "cousin germaine" of the King of Persia (Nixon 1607: K4 ${ }^{\mathrm{v}}$ ). About this, Samuel Chew explains that Robert married one Teresa Sampsonia, a relative of one of the Shah's wives, and by no means a Muslim but an Orthodox Christian (Chew 1937: 299). Ross also tells that Teresa (as it seems, a woman of great intelligence and personality) accompanied Robert in his travels to different European courts (Ross 1933: 80; Davies 1967: 226-227, 272).

In the play, however, Teresa is both the Shah's niece and a Shi'a Muslim, and notwithstanding this she clearly prefers the Christian foreigner over his most likely suitor, Cushan Hallibeck, the Persian courtier and ambassador. The play here advocates the traditional topical distribution of sexual roles: passive oriental female and active but chaste Christian/English male, but after a close analysis we witness a certain reversal of roles that, if not completely, partially disturbs our preconceptions. Thus, whereas the Sophy's niece falls in love with the youngest Sherley brother on account of his masculinity despite religious differences (Travailes, 3.108-118), for the niece's maid Dalibra these foreigners are not the expected active predators of a passive, lustful oriental femininity, but simply another male object of consumption: "if they be as pleasant in tast as they / are fayre to the eye, they are a dish worth eating" (ibid. 3.5-6); and when it comes to sexual performance "I make no question [foreigners] can do aswel if it came once to execution" (ibid. 3.24-25). But even if we interpreted these statements not as instances of sexual relativism but as an attempt to

16 Cf. Todorov (1984: 185-202) on the nature of dialogue established between the Spaniards and the peoples they encountered in the New World.

17 On the fascinating figure of Teresa Sampsonia, who may be described halfway between "voluntary" and "involuntary" travelers, cf. Andrea (2015: 291-307). Cf. also Andrea (2007), where the author considers Teresa Sampsonia's travels with Robert Sherley as a subtext of Lady Mary Wroth's prose romance Urania (1621); cf. also Andrea (2005: 279-295), where Bernadette Andrea claims that Teresa Sampsonia was the first Persian woman ever to visit England. 
The Travailes of the Three English Brothers and the Textual Construction

underline the expected lasciviousness of Persian women, the Sophy's niece does express one of the first symptoms of the play's discomfort with a simple and primary scripting of the foreign in English/Christian terms, her speech certainly revealinga slightly less unprejudiced view of this Persian woman on the part of the playwrights:

Dal. And what did you dreame of them?

Nie. A very profitable dreame, which tells me that as strangers

are amorous so in the end they prowe dangerous, and like

the industrious bee, hauing suckt the juyce of

forraine gardens they make wing to their owne homes and

there make merry with the fraught of their aduentures.

(Ibid. 3. 124-129)

Set in the context of a play that dealt with a historical and failed attempt to join all Christian princes - Catholic and Protestant - against Muslim Turkey, theological differences between Turkish Sunnis and Persian Shiites ${ }^{18}$ must have appeared familiar to an English audience composed of a Protestant majority and some crypto-Catholics, especially in the context of - as I already mentioned - Anthony's and Robert's notorious conversions to Catholicism. This is probably why the play does have a Christian but not a Protestant or Anglican agenda, and it is only in this context that we can understand the very positive portrait of the Pope that the playwrights give: "the Father of our Mother Church" (Travailes, 5.38) and "the mouth of Heaven" (ibid. 5.46). To be sure, there are some references to dissension within Christendom, and to how this may be used by pagans to explain their resistance to the one and true religion: the Turkish jailor of Sir Thomas justifies his cruelty on Christian division: "why should we do any better / to them, since they do little better one to another?" (ibid. 12.14-15).

It must also be noted that Sir Anthony's career in Spain (which the Chorus dressed as 'Fame'explicitly mentions in the epilogue of the play) must have

18 The play identifies the major differences between Sunnis and Shiites as the main cause of the conflict between Turkey and Persia, something which is not as surprising as it may seem since Knolles, some years earlier in his Generall History of the Turkes (1603), had already explained that this was the main cause for the hostility between these two kingdoms: the legitimacy of these various caliphs, and not "the divers interpretation of their law ... which amongst the Turks and the Persians is all one." (Knolles 1603: vol. I, 316). However, none of these two Muslim sects considered any of these successors of Muhammad as gods or "deities", like the play seems to claim (Travailes, 1.87-89; $1.157-58)$. 
LÓPEZ-PELÁEZ CASELLAS

made it very clear that he already was a Catholic, just like his brother Robert and, very likely, Robert's wife Teresa (Andrea 2005: 86-89). In spite of this, the Catholic-Protestant division is never addressed in the play; this glaring omission - in the context of constant allusions to sectarian divisions within Islam - makes religious dissension among Christians an ominous subtextual presence (an 'absent presence') in the text. Thus, the play seems to suggest that, just like Muslims, Christians are unnecessarily divided by relatively minor theological nuances, a similarity that seems to, again, weaken the kind of religious criticism that we might expect from a play that is supposed to be involved in a confrontation between Christendom and Islam in a more straightforward way.

But there is an additional religious element that deserves attention, as the play introduces, together with the Muslim complexities of Mortus Ally and the three other caliphs (or the controversy between divine right and the principle of succession), various references to pre-Islamic religious creeds. Mazdeist and Zoroastrian beliefs appear here and there in a strange combination with Muslim thought, especially in the longest theological discussion of the play, when Sir Anthony employs a Platonic argument to demonstrate the superiority of Christian over Persian beliefs (Travailes 2.189-237). Also, when confronted with Persian pre-Islamic adoration of the sun and the moon (essentialised as a millenary practice), which are described as the two deities that give "this light by which we see", Sir Anthony answers that "The maker still is better then his worke." (ibid. 2.208). According to the two first modern editors of the play, Fuad Sha'ban and Abdul Ridha, this anachronism of introducing pre-Islamic religious practices in Safavid Persia basically exemplifies the misconceptions and misrepresentations of early modern England (and Europe) when confronting the so-called Muslim other: non-Christian religious practices are inevitably misrepresented as polytheistic and pagan, mixing superstition with ancient religion, and these with Islam. (Sha'ban 1965: 89-91, 109-12; Ridha 1973: 23.

According to Javad Ghatta this was part of the complex religious picture that the Sherleys, and other travelers with them, actually found in late sixteenth and early seventeenth century Persia, where the old pre-Islamic religion was still present as an ideological device to legitimise current Muslim Safavid rulers through a link with ancient Persian kings (Ghatta 2009: 241). For all the apparent simplicity of a travel and adventure play, Travails - unlike any other English early modern play - dramatises, in all its complexity, the multiple Persian identities - Mazdaist, Zoroastrian, Muslim - coexisting during the reign of the Safavid monarch Shah Abbas. What is of interest here is that, rather 
than another conventional and distorted dramatization of Islam of the kind provided by many early modern plays, what we may have here is a sophisticated approach to Persian ideological construction of a complex religious and social identity. In this sense, Ghatta argues that this play is an "early example of Western popular awareness of the multiple identities which coexisted in Safavid Persia" (ibid. 240). I believe that through the play's reproduction of this religious symbiosis (splendidly exemplified in the figure of the Great Sophy) the authors have captured Persia's strategic investment in an Iranian, pre-Muslim legacy that attempted to create an identity that opposed Ottoman Sunnite hegemony (ibid. 245).

In 1581 Francis Drake was knighted by Queen Elizabeth on board the Golden Hind, and with this solemn act privateering and piracy were unofficially approved by the monarch as acceptable economic activities, although they kept an ambiguous ethical status (Hakluyt 1904: 12,16). As a consequence, during the sixteenth and seventeenth centuries English merchant ships would turn to piracy if there was a good chance of obtaining a profit, which is precisely what the historical Sir Thomas Sherley tried to do (with meager results) in his five privateering expeditions and by infamously plundering some Mediterranean islands (Davies 1967: 62-72, 172-76; Sha'ban 1965: 113-14). Interestingly, neither Nixon's or Sir Thomas' accounts, nor the play, mention the actual nature of the eldest brother's expeditions, which are transformed, both by them and in the play, from simple acts of pillage over peaceful Greek islanders into honorable military raids against the Ottoman enemy. However, and although there is a sustained concern in the play, as we saw, with presenting the three brothers' adventures in the light of honorable actions, it also manifests some discomfort with the new (emergent) economic structure of feeling that the Queen's decision of 1581 seemed to sanction. As a result, Travailes consistently problematises all references to the new economic scenario of the early seventeenth century.

To begin with, the play betrays an anxiety with the new economy by significantly identifying those who brought about Sir Thomas's misery as "divers merchants" who "corrupt(ed) his men" (Travailes 6.17), and it signals greed as the major reason for the sailors' decision to desert and betray Sir Thomas: "what pillage we can make our prey / 'Twill be our own, and we to none obey" (ibid. 6.88-89). To be more precise, Travailes consistently shows a certain degree of unrest with the kind of mercantilism, or nascent capitalism, that was evidently emerging in the England that the brothers had left behind, and that actually sent both Sir Thomas the elder to the Fleet (in 1604) and his eldest son Thomas to the Tower (in 1607). Actually, Sir Thomas's Discours of the 
Turks (1607-08), ${ }^{19}$ for all its typical Sherleian patriotic tone, bitterly criticises England for being the only Christian nation selling to the Turks "powder \& other munition for warre", a commercial transaction that he describes as "abhominable \& naughte, \& bringeth mutche sclaunder to our nation \& religion" (Ross ed. 1936: 9). Mercantilism, for Sir Thomas, must be set some limits, and England seems to be trespassing them: "There are noe Christian shippes that trade with the Turke that wyll carye anye of these, but onelye the Englishe, all the others utterlye refusing to doe the Turkes soe uncharitable a servis." (Ibid. 11.) This ambivalent relation with a new economic context in the case of Sir Thomas (who strongly opposed trading with the Turks) extends to the play as a whole, and The Travails of the Three English Brothers clearly addresses economy as one central location of conflict between seventeenth century (honorable) Englishmen and the most iconic representatives of this new mentality, namely Jews, as the Venetian episode with Zariph the Jew shows (scenes nine and ten).

As Christopher Hill famously argued, the early modern transition towards proto-capitalism brought about, beyond the merely economic, a major epistemological shift: "This was in itself a moral as well as an economic revolution, a break with all that men had held right and proper, and had the most disturbing effects on ways of thought and belief" (Hill 2012). In a play like Travailes, this "revolution" seems to relate in complex ways to other issues previously mentioned, like religious differences and conflict, ethical compromise, or cultural exchange. It is in this sense that I understand the episode between Sir Anthony and the Jewish money-lender Zariph. Strategically placed in Venice and only remotely connected to a real event during the embassy (Davies 1967: 149-65) it resonates with echoes of Shakespeare's Merchant of Venice (1596-98), developing in some detail not necessarily or exclusively an anti-Jewish prejudice as much as the conflict between the (residual, in Raymond Williams's terms) feudal economic and epistemological system, and a new - emergent - proto-capitalist society.

The new economy represented by Zariph is rejected by Sir Anthony as, for all the anti-Jewish prejudice which the play evidently shows ("A Christian's

19 Samuel Chew dates the treatise in 1617, while Sir Thomas was in Fleet prison; E. Denison Ross gives a much more reliable dating, 1607-08, based on a reference to the Diet of Ratisbon; according to Ross, the text was composed from notes taken while Sir Thomas was at Constantinople (we know he stayed there for a few months after being freed), and put together on the way back to England (Ross ed. 1936: iii-x). Davies agrees on the dates with Ross, and suggests that the Discours of the Turks may be the so-called Treatise on the Levant Trade (1967: 182-185). 
torture is a Jew's bliss" Travailes, 10.38), the Jew also (and, I believe, primarily) stands for that new society that started to abandon, in the early seventeenth century, a gift-exchange mentality characteristic of the previous age, in order to replace it with the new economy. This transition implied a clear disruption of traditional social relations: a community ordered by a gift-exchange dynamics, typical of medieval societies, reproduces an ethics of neighbourliness, i.e., the old reciprocity nexus, whereas a society based on commodity exchange relations, of the kind emerging in the early modern period, is mostly based on profit and economic gain. Furthermore, Travailes - like Shakespeare's Merchant - is at pains to evince the contrast between two very different types of capitalist, merchant and usurer, who are embodied, the play suggests in these two scenes, by - respectively - Sir Anthony and Zariph (or Antonio and Shylock). In my reading of the play, Zariph is a despicable character not only because he is a Jew, but because he practices this new economy which allows him to hold an asymmetrical advantage in his dealings with others and, more specifically, with Sir Anthony Travailes, 10.1): ${ }^{20}$ he is a Jew because he is an usurer as much as the other way round.

Zariph manifests his happiness, first, that someone owes him "a hundred thousand ducats" (Travailes 10.1), and only then satisfaction that the debtor is a Christian: "Sweeter still: who owes it? A Christian", someone who, if the "bond [is] unsatisfied," will be "in the Jew's mercy" (ibid. 3.5-6). Of special significance is the exchange between the English gentleman and the (proto)capitalistic Jew, which displays the clash between an aristocratic mentality (the play emphasises Sir Anthony's lavish spending and prodigality) (ibid. 10.4142) and an economicist money lender. ${ }^{21}$ To Sir Anthony's appeals to Christian and moral virtues: "I must intreat you of forbearance Zariph," (Travailes, 9.24) the Jew answers with a cold economic reasoning: "You had my Iewell, I must have your Gold.” (Ibid. 9.26.) If Sir Anthony invokes an alleged past friendship with the Jews: "Let me intreat thee Zariph for my sake / That haue stood friend to all thy brethren” (ibid. 9.27), Zariph responds by alluding to Christian dealings in slave trading: "You sold my brother Zacharie like a horse / His wife and children at a common out-crie." (Ibid. 9.30-31.) Interestingly, Sir Anthony now turns to their common condition as strangers in Venice: "I am like thee, a stranger in the Citty: / Strangers to strangers should be pitifull."

20 Cf. Singleton (2011: 685-87) on the notion of 'equality of advantage' in the sixteenth and early seventeenth centuries; cf. the infamous treaty by Martin Luther on Jews and usury (Luther 1997).

21 This was a well-known characteristic of the historical Sir Anthony; cf. Davies 1967: 147-51; Chew 1937: 239-40, 285-86. 
LÓPEZ-PELÁEZ CASELLAS

(Ibid. 9.35-36.) When Zariph finally gives Sir Anthony one extra day to pay his debt, the latter still tries to re-direct this exchange through the old reciprocity nexus, based on mutual trust and friendship, by inviting Zariph to a banquet: Sir Anthony wants to fit the exchange into the familiar (residual) terms of a gift-exchange mentality, but the money-lender refuses to accept that now obsolete form of economic relation (ibid. 9.50).

Economic conflict of the kind expressed by this encounter between Sir Anthony and Zariph is, to be sure, one more of the confrontations between opposing communities and cultural groups that articulate the play (Holland 1996: 168). It must be noted that William Parry's reference to a wicked friar (an episode that would entail some form of criticism of Christians) (Ross 1933: 125-32), or Nixon's description of a merciful Jew who helped Thomas Sherley during his imprisonment in Turkey, find no room in Travailes (Nixon 1607: D4-E). As it seems, the playwrights considered it more appropriate to concentrate on the prototypically villainous figure of the Jew already popularised by Shakespeare's Shylock and Marlowe's Barabas. In this way, the playwrights are able to emphasise the triangle of cultures (Christian, Turkish and Persian) that shape the play, leaving the opposition between Zariph and Sir Anthony (together with those between Ottomans and Christians at large) as the only unsurmountable conflict in the play. This opposition, however, is not so much built around the Christian versus Jew conflict (thick with intertextual resonance as it is) as a consequence of the epistemological confrontation existing between a representative of the class of the gentleman merchant (Sir Anthony) and a money-lender and an usurer (Zariph).

\section{Play(s) within the Play}

It is probably the metatheatrical dimension of the play that which most clearly introduces some degree of uncertainty within the play's apparent compliance with a monological discourse about the superiority of English and Christian over the non-Christian and the non-English Other. It is generally accepted that early modern theatre played a decisive role in the ideological construction of aliens and foreigners; in Ania Loomba's words: "the theatre deeply shaped English imaginings of outsiders" (Loomba 2002: 8). Indeed, it was to a great extent through theatrical representations (and travel narratives) that early modern Englishmen and women experienced cultural difference and witnessed ways to cope with that difference; and these ways, it must be noted, frequently went beyond the simple scripting as evil, and consequent rejection, 
The Travailes of the Three English Brothers and the Textual Construction

of everything that was perceived as alien or opposed to 'us'. ${ }^{22}$ Brinda Charry and Gitanjali Shahani have already noted the major role played by theatre in exploring the significance of intercultural exchange for an early modern society; in their introduction to Emissaries in Early Modern Literature and Culture Charry and Shahani explain how some early modern plays (and they specifically mention Day, Rowley and Wilkins's Travailes) challenge monological representations of identity categories, introducing in their depictions, like English authorities were starting to do in their relations with foreigners, some degree of "flexibility" (Charry and Shahani 2009: 8). But plays and theatrical representations also interacted with travelers and their accounts of exotic destinations in more subtle ways. According again to Charry and Shahani, "all travelers were inevitably spectators" (ibid. 11) since host cultures carefully selected the scenes they were allowed to see, the places they could visit, or the people they could talk to. From these episodes travelers then had to extract an array of meanings they could use for their own (or their Companies') benefit, which involved and included making them cohere for their audiences back home. In other words, travelers had to be able to reverse their function from addressees to addressors, i.e., emissaries turned emissors, who were compelled to employ "public gesture and conspicuous display" (Parr 1996: 23).

A travel play could eventually become the representation of a representation, to the extent that characters/actors, travelers and their hosts, and audience, all shared and employed similar semiotic devices in order to decodify the messages produced and received. Clearly then the opening scene of Travailes, with the display of battles (one Persian, one Christian), introduces early on in the play a metatheatrical concern that will never be abandoned. Through these two rehearsals the two Sherleys significantly progress from functioning asprivileged audience of the Persian mock battle to staging their own military display, through which they gesture towards what, as I suggested above, became one of the play's central concerns, namely Christian and English difference exemplified through the notion of honor.

Theatrical self-consciousness is then, from the onset, a central concern of this play, not the least because - as has been noted - Travailes exists in a very special relation to the events it dramatises (the Sherleyan narrative of cosmopolitan adventures) unfinished as they were in 1607 and suspiciously at odds with their theatrical version. That much of the audience could be aware of the Sherleys' dubious allegiances, repeated failures, dishonesty, and conversion to Catholicism (in the case of Robert and Sir Anthony) only adds to the play's

22 For some recent studies on then representation of foreigners and aliens in early modern English texts cf. Singh ed. 2009; López-Peláez ed.2011; cf. also Ahrens ed. 2013. 
metatheatrical qualities (common to a certain extent to all travel plays, as noted above) and to a paradoxical relation with itself and with the events dramatised. But this extreme form of theatrical awareness - enhanced through dumb shows, mock battles, parades etc... - reaches its climax in the scene that brings together Sir Anthony Sherley and, of all people, the actor Will Kemp (Travailes 9. 52-144). Based on a probable historical encounter (Davies 1986: 95), ${ }^{23}$ in this scene Kemp discusses different approaches to acting with an Italian Harlequin (which eventually produces a comic confusion of play-roles with real-life people, namely, Harlequin's wife). This explicit allusion to the play's metatheatrical nature presents the audience with - in Neville Davies's cleverly convoluted phrasing - "an actor [who] acts the role of a known actor who creates humour by confusing stage roles with actual reality in a performance of a performance that masquerades as a rehearsal" (Davies 1986: 95-96). This encounter and the discussion that Kemp introduces unsettle - in my reading identity categories, especially those related with the notions of 'performance' and 'reality' (Charry and Shahani 2009: 13), since - as Kemp argues - "good fellows [in England] live upon credit" (Travailes, 9.56-59). And this awareness of the fabricated nature of reality, paradoxically enough, works to undermine precisely what the play set out to establish in the first place, ie, the Sherleys' reputation as true English ambassadors and heroes.

\section{Conclusion}

In spite of all the discontinuities and contradictions I have discussed so far, it is probably within the play's dramatic structure where we can find the most significant paradox. This is articulated in the form of a divide between what the play shows as theatrical reality and what the brothers notoriously did not achieve or could not do. Thus, Travailes consistently reproduces a dynamics of representation and misrepresentation, and this inadvertently and eventually seems to contribute to a problematization of the pretended patriotic images of the three brothers. Sir Anthony is and is not the Sophy's representative; Robert is and is not the Persian substitute, and he is and is not dead; or, like explained

23 Samuel Chew is the only author who provides a contemporary source referring to this encounter, The Diary of William Smith of Abington (Chew 1937: 274-76). Why the two men met in Rome, and why Kemp, an actor, behaved with such familiarity with a lower member of the aristocracy such as Sir Anthony, remains to be explained; one possible explanation is that they might have been related, since the maiden name of Anne Sherley, Sir Anthony's mother's, was 'Kempe'. Chew also suggests that Sir Anthony must have been well known by London dramatists. 
The Travailes of the Three English Brothers and the Textual Construction

in the Prologue, the play is and is not a faithful representation of "truth" (ibid. Prologue, 5). In this sense, the promise expressed in the opening of the play through the metaphor of the cook is not fulfilled: "Who gives a fowl unto his cook to dress/Likewise expects to have a fowl again" (ibid. Prologue, 9-10). The play has not been able to consistently fashion the adventures of "Honour's favourites" (ibid. Dedicatory Preface), and has provided us instead with a disjointed account of conflicting relations with Persians, Ottomans, early capitalists, women and actors.

From my reading of Day, Rowley and Wilkins's The Travailes of the Three English Brothers it follows that this play does not produce an imperial or protocolonial rhetoric in a straightforward way. Instead, I have suggested that what we find is a symbiotic ideological process in which the expected prejudice paradoxically and inevitably turns into something different and more complex: as we have seen, the initially alleged English military superiority is eventually not so clearly asserted; Persians (especially females) are not consistently diminished as dishonorable or lascivious and passive objects of consumption; complex religious identities seem to be acknowledged; the conventional rejection of the Jew is addressed as a conflict between old and new systems of economic organization; and the whole Sherleyan adventure is eventually projected as a theatrical display. ${ }^{24}$

All these issues are expressed in familiar terms for an early modern English audience which - together with prejudice against foreigners or aliens - was also much concerned with England's conflictive transition towards capitalism and her protocolonial expansion. This is not to say that the play clearly subverts its original and strong impulse to script the Ottoman and Jewish others in order to reproduce a robust English early modern identity, but I believe that, especially if we put all these uncertainties in relation with the meta-theatrical game of allusions between 'facts' and fiction that all the sources and related narratives suggest, The Travailes of the Three English Brothers can be argued to simultaneously affirm and interrogate the construction of England's irreducible others in unexpected and challenging ways.

24 Significantly given Sir Anthony's reputation as a charlatan and liar, one of the first topics in the conversation between Sir Anthony and Will Kemp is England's Joy, the 1602 theatrical hoax. 
LÓPEZ-PELÁEZ CASELLAS

Jesús López-Peláez Casellas

jlopez@ujaen.es

Departamento de Filología Inglesa, D2-245

Universidad de Jaén

23071 Jaén

ESPAÑA / SPAIN

\section{References}

Ahrens. R. et al., eds. 2013. The Construction of the Other in Early Modern Britain: Attraction, Rejection, Symbiosis. Heidelberg: Universitätsverlag Winter.

Andrea, B. 2005. Lady Sherley: The First Persian in England? - Muslim World, 92/5, 279-295.

Andrea, B. 2007. Women and Islam in Early Modern English Literature. Cambridge: Cambridge University Press.

Andrea, B. 2015. The Presences of Women from the Islamic World in Sixteenth to Seventeenth Century British Literature and Culture. - M. E. Wiesner-Hanks, ed., Mapping Gendered Routes and Spaces in the Early Modern World. Farnham: Ashgate, 291-307.

Burton, J. 2009. The Shah's Two Ambassadors: The Travels of the Three English Brothers and the Global Early Modern. - B. Charry and G. Shahani, eds., Emissaries in Early Modern Literature and Culture. Farnham: Ashgate, 23-40.

Calendar of State Papers. Colonial, East Indies, China and Japan (Volume 2, 1513-1616, 'East Indies: December 1599'). 1864. W. N. Sainsbury, ed. London: Her Majesty's Stationery Office.

Calendar of State Papers. Domestic (1601-1603). 1870. M. A. Green, ed. London.

Cartwright, J. 1611. The Preachers Travels. London.

Charry, B. and G. Shahani. 2009. Introduction. - B. Charry and G. Shahani eds., Emissaries in Early Modern Literature and Culture. Farnham: Ashgate,1-22.

Chew, S. 1937. The Crescent and the Rose. Islam and England during the Renaissance. New York: Oxford University Press.

Cohen, A. 1993. Culture as Identity: An Anthropologist's View. - New Literary History, 24, 195-209.

Davies, H.N. 1986. Pericles and the Sherley Brothers. - E. A. J. Honigmann, ed., Shakespeare and His Contemporaries: Essays in Comparison. Manchester: Manchester University Press, 94-113.

Day, J., Rowley, W., Wilkins, G. 1607. The Travailes of the Three English Brothers. London.

Ghatta, J. 2009. 'By Mortus Ali and our Persian gods': Multiple Persian Identities in Tamburlaine and The Travels of the Three English Brothers. - Early Theatre, 12/2, 235-249.

Hakluyt, R. 1904. Principal Navigations (vol. 12). Glasgow \& New York: Macmillan. 
The Travailes of the Three English Brothers and the Textual Construction

Hernández de Jorquera, F. 1987 [1646]. Anales de Granada. Granada: Universidad de Granada.

Hill, C. 2002 (1940) The English Revolution 1640. - http://www.marxists.org/archive/ hill-christopher/english-revolution/. Transcribed by A. Blunden (10.05.2016).

Houston, C. 2009. 'Thou glorious kingdome, thou chiefe of Empires': Persia in early seventeenth-century travel literature. - Studies in Travel Writing, 13/2, 141-152.

Holland, P. 1996. 'Travelling hopefully': The dramatic form of journeys in English dramatic drama. - J.-P. Maquerlot and M. Willems, eds., Travel \& Drama in Shakespeare's Time. Cambridge: Cambridge University Press, 160-179.

Knolles, R. 1603. The Generall Historie of the Turks. London: Adam Islip.

Loomba, A. 2002. Shakespeare, Race and Colonialism. New York: Oxford University Press.

López-Peláez Casellas, J., ed. 2011. Strangers in Early Modern English Texts. Frankfurt: Peter Lang.

Lotman, J., Uspenskij, B. 1978. On the Semiotic Mechanism of Culture. - New Literary History, 9/2, 211-232.

Luther, M. 1997 [1524]. On Trading and Usury. (Albany, OR: Books for the Ages.)

McJannet, L. 1999. Bringing in a Persian. - Medieval and Renaissance Drama in England,12, 236-267.

Nixon, A. 1607. The Three English Brothers. London.

Parr, A. ed. 1995. The Travels of the English Brothers. - A. Parr, ed., Three Renaissance Travel Plays. Manchester \& New York: Manchester University Press, 55-134.

Parr, A. 1996. Foreign Relations in Jacobean England: The Sherley Brothers and the 'Voyage of Persia'. - J.-P. Maquerlot, M. Willems, eds., Travel \& Drama in Shakespeare's Time. Cambridge: Cambridge University Press, 14-31.

Persia, D. J. de (Uruch Beg) 1929 [1604]. Don Juan de Persia. A Shi'ah Catholic. E.D. Ross, E. Power, eds. Trans. G. Le Strange. London: Harper The Broadway Travellers.

Ridha A. R. M. 1973. A Critical Edition of John Day, William Rowley, and George Wilkins' The Travailes of the Three English Brothers. Diss. Thesis. The University of Nebraska-Lincoln.

Ross, E. D. 1933. Sir Anthony Sherley and his Persian Adventure. London: The Broadway Travellers.

Ross E. D, ed. 1936. Thomas Sherley. Discours of the Turkes. London: Offices of the Royal Historical Society.

Schleck, J. 2011. Telling True Tales of Islamic Lands. Selinsgrove, PA: Susquehanna University Press.

Sha'ban, F. 1965. The Mohammedan World in English Literature, ca. 1580-1642. Illustrated by a Text of The Travailes of the Three English Brothers. Diss. Thesis. Duke University.

Sherley, A. 1613. Sir Anthony Sherley his relation of his travels into Persia. London.

Sing, J.G. ed. 2009. A Companion to the Global Renaissance. English Literature and Culture in the Era of Expansion. Malden: Wiley-Blackwell. 
LÓPEZ-PELÁEZ CASELLAS

Singleton, J. D. 2011. 'Money Is a Sterile Thing': Martin Luther on the Immorality of Usury Reconsidered. - History of Political Economy, 43/4, 683-698.

Subrahmanyam, S. 2011. Three Ways to Be Alien: Travails and Encounters in the Early Modern World. Lebanon, NH: Brandeis University Press.

Talvet, J. 2013. 'Self' and 'Other'. Thinking with Montaigne, Liiv and Lotman. R. Ahrens et al., eds., The Construction of the Other in Early Modern Britain: Attraction, Rejection, Symbiosis. Heidelberg: Winter, 13-26.

Todorov, T. 1984. The Conquest of America. The Question of the Other. New York: Harper and Row.

Williams, S. ed. 1861. Letters Written by John Chamberlain during the Reign of Queen Elizabeth. Westminster: Camden Society \& J. B. Nichols \& Sons. 